\title{
STRUCTURE AND TRENDS OF FORESTS FORMATION IN THE CENTRAL PART OF LAKE BAIKAL EASTERN SHORE
}

\author{
Alexander Sizykh \\ Siberian Institute of Plants Physiology and Biochemistry of RAS SB, 664044, Irkutsk, 132 Lermontova str., Russia; \\ Corresponding author Alexander Sizykh, e-mail: alexander.sizykh@gmail.com;
}

Received December 2019; Accepted January 2020; Published February 2020;

DOI: https://doi.org/10.31407/ijees10.122

\begin{abstract}
The studies of structural-dynamic organization of forests in the central part of Lake Baikal eastern shore performed using method of field geobotanic survey (at the key sites) revealed modern trends of the formation of forest communities under different physical-geographic conditions in the Eastern Pre-Baikal in the whole. In particular, we noticed expansion of dark-coniferous trees species as undergrowth, at initial stages of timber stand formation, with appearing in the second synfolium suggesting spatial widening of a dark-coniferous component in taiga structure on the background of climate dynamics during last decades in the region. Common features of forest communities at the key sites - the Tolbazikha and Manturikha river valleys (south-eastern coast of Lake) is strengthening of darkconiferous species position in the undergrowth of polydominant dark- and light-coniferous forests. Often on burnt sites and cuttings under the canopy of small-leaf timber stand, there is undergrowth of trees forming dark-coniferous taiga (cedar, spruce, fir) characteristic for pre-mountain region of the Khamar-Daban Ridge. According to the integrated studies data consisting of plants species composition, geoelemental (arealogical) and ecotypological (ecotypes) compositions, to ratio of belt-zonal plants groups in the communities and to structural-dynamic variability of communities with time for these physical-geographic conditions, we have to state that at present there are trends of substitution of dark-coniferous - light-coniferous taiga by dark-coniferous component everywhere. Such trends in the forests formation were noticed before several times for Lake Baikal southern and western shores, as well as in the whole Baikal Region.
\end{abstract}

Key words: geobotanic survey, structural-dynamic organization of forests, south-eastern coast of Lake Baikal, darkconiferous - light-coniferous taiga 